\title{
Aumento de Membresia ou reconfiguração eclesial? Um estudo pastoral sobre Pequenos Grupos em Igrejas Batistas do Estado do Espírito Santo
}

\author{
Orientador: Joel Portella Amado \\ Doutorando: Valdir Stephanini \\ Área de Concentração: Teologia Sistemático-Pastoral \\ Linha de Pesquisa: Fé e Cultura
}

Esta tese visa investigar até que ponto a inserção de Pequenos Grupos em duas Igrejas da denominação Batista no Estado do Espírito Santo tem sido utilizado como ferramenta estratégica para a reconfiguração eclesial ou apenas como recurso para o aumento de sua membresia. A tese está organizada em três capítulos. O primeiro capítulo apresenta uma abordagem histórica sobre o surgimento do movimento batista e de que maneira tradicionalmente se configuram as Igrejas filiadas à Convenção Batista Brasileira. Este capítulo também se ocupa em apresentar algumas experiências de Igrejas Cristãs que, ao longo da história do Cristianismo, têm adotado os Pequenos Grupos como estratégia de funcionamento eclesiástico. Nesta discussão sobressaem dois modelos: Igrejas Dirigidas por Propósitos e Igrejas organizadas de acordo com a filosofia do Ministério Igreja em Células. A Igreja Batista em Jardim Camburi e a Igreja Batista em Morada de Camburi, objeto material desta tese, são apresentadas a partir de suas histórias. O segundo capítulo refere-se ao objeto formal, a saber, Eclesiologia de Comunhão. Esta categoria teológica se fundamenta na relação existente entre as três pessoas da Trindade divina, inspirado, sobretudo nas reflexões do Concílio Vaticano II. O terceiro capítulo apresenta os resultados da Pesquisa Social realizada com os membros das duas Igrejas Batistas já mencionadas. Foram destacadas doze categorias da Eclesiologia de Comunhão. Analisou-se até que ponto estes valores estão presentes nas igrejas pesquisadas, com o objetivo de indicar se os Pequenos Grupos contribuem para uma reconfiguração das referidas Igrejas na direção da Eclesiologia 
de Comunhão. O conteúdo das cento e vinte entrevistas realizadas com os membros duas Igrejas pesquisadas foi transcrito na íntegra e apresentado em forma de anexo.

Palavras-chave: Igreja. Pequenos grupos. Células. 